\title{
Effect of crop stage and leaf number for topping on performance of bidi tobacco (Nicotiana tabacum L.) rainfed vertisols
}

\author{
S. Jaffar Basha*', P. Pulli Bai ${ }^{1}$, K. Prabhakar' ${ }^{1}$, J. Manjunath ${ }^{1}$, \\ S. Kasturi Krishna ${ }^{2}$ and C. Chandrasekhara Rao $^{2}$ \\ ${ }^{1}$ Regional Agricultural Research Station, Acharya N. G. Ranga Agricultural University, Nandyal-51850, \\ Kurnool District, Andhra Pradesh, India \\ ${ }^{2}$ All India Network Project on Tobacco, ICAR-Central Tobacco Research Institute, Rajamahendravaram, \\ Andhra Pradesh, India
}

*Corresponding Author: shaik.jaffarbasha@gmail.com

[Accepted: 19 August 2020]

\begin{abstract}
A field experiment was undertaken at Regional Agriculture Research Station, Nandyal, Andhra Pradesh from 2016-17 to 2018-19 vertisols under rainfed condition to find out the optimum crop stage and leaf number for topping in bidi tobacco (Nicotiana tabacum) for higher cured leaf yield and quality. The experiment consists of 11 treatments (combination of button, early flowering stages for topping leaving 8, 9, 10, 11 and 12 leaves). The experiment was laid out in randomized block design with three replications. Significantly higher cured leaf yield (1660 kg $\mathrm{ha}^{-1}$ ) was recorded with control (topping at early flowering stage keeping 15 leaves) and was at par with topping at early flowering stage keeping 12 leaves $\left(1628 \mathrm{~kg} \mathrm{ha}^{-1}\right)$ and topping at button stage keeping12 leaves $\left(1587 \mathrm{~kg} \mathrm{ha}^{-1}\right)$. The leaf chemical parameters i.e., nicotine, reducing sugars and chlorides did not differed significantly due to different topping crop stage and leaf number. The nicotine values were ranging from $5.30 \%$ to $5.80 \%$ whereas reducing sugars were from $2.91 \%$ and $3.32 \%$ and chlorides from $1.24 \%$ to $1.75 \%$ and were in permissible limits with respect to quality. The topping at early flowering stage keeping 15 leaves recoded higher net returns (Rs 71,550 ha-1) and benefit : cost ratio (2.35) followed by topping at early flowering stage keeping 12 leaves (Rs 69,150 ha ${ }^{-1}$ and 2.31) and topping at button stage keeping 12 leaves (Rs 66,075 ha $^{-1}$ and 2.25). Reduction in cured leaf yield was observed in topping either at bud or early flowering stage keeping from higher (15 leaves) to lower number of leaves (8 leaves).
\end{abstract}

Keywords: Bidi tobacco - Topping - Crop stage - Leaf number - Cured leaf yield.

[Cite as: Basha SJ, Bai PP, Prabhakar K, Manjunath J, Krishna SK \& Rao CC (2020) Effect of crop stage and leaf number for topping on performance of bidi tobacco (Nicotiana tabacum L.) rainfed vertisols. Tropical Plant Research 7(2): 508-511]

\section{INTRODUCTION}

Bidi tobacco (Nicotiana tabacum L.) is commercially cultivated under rainfed vertisols in late rainy season i.e., September ( $2^{\text {nd }}$ fortnight) in Andhra Pradesh. The rainfed agriculture suffers from a number of hydrophysical and socio-economic constraints, which affect the productivity of rainy and post-rainy season crops. These include erratic and undependable rainfall, excess and deficient moisture within a season and low level of input use (Gupta 2002). Topping (removal of the flowering head and young leaves) is an essential cultivating measure to maximize leaf production and encourage leaf-ripening for air-cured tobacco, which switches the plant from reproductive to vegetative phase (Guo et al. 2011, Gooden et al. 2011, Czubacka et al. 2012). Topping increases the size and weight of leaves, increasing the overall yield per hectare (Singh et al. 2000, Reed et al. 2012). Topping is the cultural practice during early button stage which gives tobacco its desired chemical and physical characteristics that lead to high quality cured leaf yield (Singh et al. 2000). In tobacco, stage of topping is important for development of agricultural measures to promote the quality of leaves (Reed et al. 2012). Many authors reported the benefit of topping in increasing the yield and quality of the leaf. The topping 
at higher level resulted in significantly higher cured leaf, bright leaf yield and total bright leaf equivalent as compared to low level of topping in FCV tobacco (Reddy et al. 1997). Farmers were adopting different levels of topping for optimum cured leaf yield and quality. Different tobacco trade companies also insisting the tobacco farmers for topping at lower number of leaves. Topping of tobacco not only increases the yield but also improves the quality of cured leaf. The topping levels may depend upon various factors like the variety, topography and climatic conditions. Release of the new variety, NandyalPogaku -1 increased the cured leaf yield when compared to the earlier variety A 119 and this variety is more robust with broad and lengthy leaf and thick midrib. The traditional practice of topping at 15 leaf stage was not possible during period of moisture stress condition after planting due to poor vegetative growth. In this context it is necessary to study the effect of different topping stages and crop stages on growth yield and quality of bidi tobacco to recommend suitable toping stage to farmers for harvesting of maximum yields with high leaf quality. Keeping these observations in view, the present investigation was designed to arrive at an optimum topping crop stage and level of number of leaves for higher cured leaf yield and quality in rainfed vertisols of Andhra Pradesh.

\section{MATERIAL AND METHODS}

A field experiment was undertaken at Regional Agriculture Research Station, Nandyal, Andhra Pradesh from 2016-17 to 2018-19 vertisols under rainfed condition to find out the optimum crop stage and optimum leaf number for topping in bidi tobacco for higher yield and quality. The soil of experimental site was medium deep black, moderately alkaline (pH-8.2), non saline (EC- $0.11 \mathrm{ds} \mathrm{m}^{-1}$ ), low in nitrogen (152.3 kg ha ${ }^{-1}$ ), medium in available $\mathrm{P}_{2} \mathrm{O}_{5}\left(32.5 \mathrm{~kg} \mathrm{ha}^{-1}\right)$ and high in available $\mathrm{K}_{2} \mathrm{O}\left(350.9 \mathrm{~kg} \mathrm{ha}^{-1}\right)$. The 11 treatments (stages of topping) consisted of $\mathrm{T}_{1^{-}}$Control (15 leaf stage at early flowering stage), $\mathrm{T}_{2^{-}} 8$ leaf at Button stage, $\mathrm{T}_{3^{-}} 8$ leaf at early flowering stage, $\mathrm{T}_{4^{-}} 9$ leaf at Button stage, $\mathrm{T}_{5^{-}} 9$ leaf at early flowering stage, $\mathrm{T}_{6^{-}} 10$ leaf at Button stage, $\mathrm{T}_{7^{-}} 10$ leaf at early flowering stage, $\mathrm{T}_{8^{-}} 11$ leaf at Button stage, $\mathrm{T}_{9^{-}} 11$ leaf at early flowering stage, $\mathrm{T}_{10^{-}} 12$ leaf at Button stage and $T_{11^{-}} 12$ leaf at early flowering stage. The experiment was laid out in a randomized block design with three replications. The bidi tobacco variety used for experimentation is Nandyal Pogaku-1 and was planted at planting geometry of $75 \mathrm{~cm} \times 75 \mathrm{~cm}$. The treatments were imposed through manual topping at respective crop stage by keeping selected number of leaves. Crop management practices like nursery raising, land preparation, $\mathrm{N}, \mathrm{P}$ and $\mathrm{K}$ fertilizer application, weed control, intercultivation, desuckering, need based plant protection and sun curing were followed as per recommended practice. The data were recorded on plant height, leaf length, leaf width, leaf thickness, spangle score and cured leaf yield at harvest. Leaf samples were analysed for chemical constituents viz., nicotine, reducing sugars and chlorides at Central Tobacco Research Institute, Rajamahendravaram. The mean values of all the quantitative characters were subjected to statistical analysis by adopting Fisher's method of analysis of variance as outlined by (Gomez \& Gomez 1984). The level of significance used in ' $\mathrm{F}$ ' test was at 5 per cent.

\section{RESULTS AND DISCUSSION}

Rainfall during crop growth period

During the experimentation period bidi tobacco nurseries were sown during July and transplanting of 45-60 days old seedlings was done during September. Rainfall during September and October was critical for transplanting and establishment of nurseries. There was lower rainfall reported during October 2016 (-78.9\%), September 2017 (-21.6\%), September 2018 (-35.1\%) and October 2018 (-95.2\%) (Table 1). The total amount of rainfall received during crop growth period (nursery to harvest) was less than the normal during 2016-17 (6.8\%) and 2018-19 (-65.8\%). The crop growth was affected after transplanting due to moisture deficit condition resulting varied cured leaf yields during the experimentation period.

\section{Growth parameters and cured leaf yield}

Pooled analysis (2016-17 to 2018-19) of the data indicated that the growth and yield parameters differed significantly due to different topping crop stage and leaf number (Table 2). Significantly higher plant height $(57.6 \mathrm{~cm})$ was recorded with control (topping at early flowering stage keeping 15 leaves) and was at par with topping at button stage keeping 12 leaves $(51.8 \mathrm{~cm})$ and topping at early flowering stage keeping 12 leaves $(51.3 \mathrm{~cm})$. Significantly lower plant height $(40.3 \mathrm{~cm})$ was observed with topping at button stage keeping 8 leaves. This could be due to lower number of leaves after topping. Significantly higher leaf length $(42.9 \mathrm{~cm})$ and leaf width $(18.3 \mathrm{~cm})$ was observed with topping at topping at button stage keeping 8 leaves. Significantly lower leaf length $(34.9 \mathrm{~cm})$ and leaf width $(14.0 \mathrm{~cm})$ was observed with topping at early flowering stage keeping 15 leaves and was at par with topping at button stage keeping 12 leaves $(40.0 \mathrm{~cm}$ and $17.9 \mathrm{~cm})$ and topping at early 
flowering stage keeping 12 leaves $(37.6 \mathrm{~cm}$ and $16.9 \mathrm{~cm})$. There was a significant difference in dry wt unit leaf area $^{-1}$ and spangle score among different treatments. There was increase in dry wt/unit leaf area due to lower level of topping i.e. at 8 leaf stage $\left(15.1 \mathrm{mg} \mathrm{cm}^{-2}\right)$ when compared to 15 leaf stage $\left(12.5 \mathrm{mg} \mathrm{cm}^{-2}\right)$. Spangle score did not differed due to topping crop stages and number of leaves and was in permissible limits. Significantly higher cured leaf yield (1660 kg ha ${ }^{-1}$ ) was recorded with control (15 leaf stage at early flowering stage) and was at par with topping at early flowering stage keeping 12 leaves (1628 kg ha $\left.{ }^{-1}\right)$ and topping at button stage keeping12 leaves (1587 $\mathrm{kg} \mathrm{ha}^{-1}$ ). Cured leaf yield increased with increase in topping level (King 1986, Reddy et al. 2003, Krishna et al. 2004). Significantly lower cured leaf yield (1159 kg ha ${ }^{-1}$ ) was observed with topping at button stage keeping 8 leaves. Similar findings of lower yields at lower topping levels (Reddy et al. 1997, Sannibabu et al. 2014).

Table 1. Rainfall during crop growth period

\begin{tabular}{|c|c|c|c|c|c|c|}
\hline \multirow{2}{*}{ Month } & \multicolumn{2}{|c|}{ 2016-17 } & \multicolumn{2}{|c|}{ 2017-18 } & \multicolumn{2}{|c|}{ 2018-19 } \\
\hline & Rainfall (mm) & Deviation (\%) & Rainfall (mm) & Deviation (\%) & Rainfall (mm) & Deviation (\%) \\
\hline July & 136.6 & -14.8 & 134.8 & -15.9 & 38.4 & -76.8 \\
\hline August & 247.0 & 47.7 & 255.6 & 36.0 & 42.2 & -76.7 \\
\hline September & 174.8 & 4.6 & 134.0 & -21.6 & 103.4 & -35.1 \\
\hline October & 16.2 & -78.9 & 124.8 & 66.2 & 4.0 & -95.2 \\
\hline November & 0.0 & -100.0 & 3.2 & -91.9 & 8.2 & -78.2 \\
\hline December & 2.0 & -9.1 & 0 & -100.0 & 3.0 & 11.1 \\
\hline January & 1.0 & -23.1 & 0 & -100.0 & 18.0 & 1185.7 \\
\hline February & 0.0 & -100.0 & 0 & -100.0 & 0 & -100.0 \\
\hline Total & 577.6 & -6.8 & 652.4 & 1.7 & 217.2 & -65.8 \\
\hline
\end{tabular}

Table 2. Effect of topping crop stage and number of leaves on growth parameters, cured leaf yield, leaf chemical parameters and economics of bidi tobacco.

\begin{tabular}{|c|c|c|c|c|c|c|c|c|c|c|c|}
\hline Trt. & $\begin{array}{r}\text { Pl.Ht. } \\
\text { (cm) }\end{array}$ & $\begin{array}{r}\text { L.Lt. } \\
\text { (cm) }\end{array}$ & $\begin{array}{r}\text { L.Wd. } \\
\text { (cm) }\end{array}$ & $\begin{array}{r}\text { Dr.Wt. } \\
\left(\mathrm{mg} \mathrm{cm}^{-2}\right)\end{array}$ & Sp.S. & $\begin{array}{r}\text { CLY } \\
\left(\mathrm{kg} \mathrm{ha}^{-1}\right)\end{array}$ & $\begin{array}{r}\text { Nicotine } \\
(\%)\end{array}$ & $\begin{array}{r}\text { Rd.S. } \\
(\%)\end{array}$ & $\begin{array}{r}\text { Chlorides } \\
(\%)\end{array}$ & $\begin{array}{r}\text { NR } \\
\left(\text { Rs ha }^{-1}\right)\end{array}$ & BCR \\
\hline$\overline{\mathrm{T}_{1}}$ & 57.6 & 34.9 & 14.0 & 12.5 & 8.0 & 1660 & 5.64 & 3.14 & 1.24 & 71550 & 2.35 \\
\hline $\mathrm{T}_{2}$ & 40.3 & 42.9 & 18.3 & 15.1 & 6.7 & 1159 & 5.48 & 3.32 & 1.33 & 33975 & 1.64 \\
\hline $\mathrm{T}_{3}$ & 42.7 & 41.9 & 18.0 & 14.3 & 6.3 & 1304 & 5.48 & 3.19 & 1.46 & 44850 & 1.85 \\
\hline $\mathrm{T}_{4}$ & 43.1 & 41.7 & 17.9 & 14.1 & 7.0 & 1364 & 5.67 & 3.28 & 1.38 & 49350 & 1.93 \\
\hline $\mathrm{T}_{5}$ & 46.6 & 41.5 & 17.3 & 13.7 & 7.0 & 1370 & 5.51 & 2.97 & 1.27 & 49800 & 1.94 \\
\hline $\mathrm{T}_{6}$ & 49.1 & 42.2 & 17.6 & 13.3 & 7.0 & 1437 & 5.30 & 3.17 & 1.50 & 54825 & 2.04 \\
\hline $\mathrm{T}_{7}$ & 48.9 & 40.4 & 17.2 & 13.3 & 6.7 & 1337 & 5.50 & 3.13 & 1.31 & 47325 & 1.89 \\
\hline $\mathrm{T}_{8}$ & 50.1 & 41.1 & 18.3 & 13.1 & 7.3 & 1427 & 5.44 & 3.30 & 1.75 & 56550 & 2.07 \\
\hline $\mathrm{T}_{9}$ & 50.8 & 40.9 & 17.2 & 13.3 & 6.7 & 1451 & 5.61 & 3.23 & 1.41 & 55875 & 2.06 \\
\hline $\mathrm{T}_{10}$ & 51.8 & 40.0 & 17.7 & 13.5 & 7.0 & 1587 & 5.35 & 3.28 & 1.26 & 66075 & 2.25 \\
\hline $\mathrm{T}_{11}$ & 51.3 & 37.6 & 16.9 & 13.8 & 7.3 & 1628 & 5.80 & 2.91 & 1.39 & 69150 & 2.31 \\
\hline S.Em \pm & 2.7 & 2.3 & 1.0 & 1.13 & 0.4 & 64 & 0.35 & 0.23 & 0.10 & & \\
\hline CD@5\% & 7.9 & 6.7 & 3.0 & NS & NS & 193 & NS & NS & NS & & \\
\hline $\mathrm{CV}(\%)$ & 9.5 & 9.9 & 10.4 & 14.4 & 9.2 & 10.5 & 9.7 & 12.5 & 17.0 & & \\
\hline
\end{tabular}

Note: Trt.- Treatments; Pl.Ht.- Plant height; L.Lt.- Leaf length; L.Wd.- Leaf width; Dr.Wt.- Dry wt/unit leaf area; Sp.S.- Spangle score; CLY- Cured leaf yield; Rd.S.- Reducing sugars; NR- Net returns; BCR- Benefit : Cost Ratio.

T1- Control (Early flowering stage - 15 leaves); T2- Button stage - 8 leaves; T3- Early flowering stage - 8 leaves; T4- Button stage 9 leaves; T5- Early flowering stage - 9 leaves; T6- Button stage - 10 leaves; T7- Early flowering stage - 10 leaves; T8- Button stage 11 leaves; T9- Early flowering stage - 11 leaves; T10-Button stage - 12 leaves; T11- Early flowering - 12 leaves.

\section{Leaf chemical parameters}

The leaf chemical parameters viz., nicotine, reducing sugars and chlorides did not differed significantly due to different topping crop stage and leaf number. The nicotine values were ranging from $5.30 \%$ to $5.80 \%$ whereas reducing sugars were from $2.91 \%$ and $3.32 \%$ and chlorides from $1.24 \%$ to $1.75 \%$ and were in permissible limits with respect to quality. The influence of topping levels on leaf chemistry was non-significant in all the chemical characters (Patel et al. 2003, Kumaresan et al. 2008, Sannibabu et al. 2014).

\section{Economics}

The topping at early flowering stage by keeping 15 leaves recoded higher net returns ( $\mathrm{Rs} 71,550 \mathrm{ha}^{-1}$ ) with benefit : cost ratio (BCR) of 2.35 followed by topping at early flowering stage by keeping 12 leaves (Rs 69,150 $\mathrm{ha}^{-1}$ with BCR of 2.31) and topping at button stage by keeping 12 leaves (Rs 66,075 ha-1 with BCR of 2.25). Lower net returns of Rs 33,975 ha ${ }^{-1}$ with BCR of 1.64 was observed with topping at button stage keeping 8 leaves. Maximum gross and net returns and benefit: cost ratio were recorded when tobacco leaves were topped at 14 leaf stage followed by 12 and10 leaf stage whereas minimum was realized in topping at 8 leaf stage (Arya www.tropicalplantresearch.com 
et al. 2011). Higher net returns and benefit: cost ratio by topping at 18 leaves stage in chewing tobacco in the vedaranyam area of Tamil Nadu (Kumaresan et al. 2001, Kumaresan \& Palanichamy 2002).

\section{CONCLUSION}

Among the field operation in tobacco, topping is important operation to enhance plant growth, development and quantity. It was concluded from the study that, taking into consideration of obtaining higher cured leaf yields coupled with better quality, bidi tobacco could be grown profitably by topping either at bud stage or early flowering stage by keeping 12-15 leaves even during period of moisture stress condition. Topping at lower number of leaves was not desirable for cured leaf yield and quality.

\section{ACKNOWLEDGEMENTS}

The authors are grateful to All India Network Project on Tobacco (AINPT), ICAR-CTRI, Rajamahendravaram and Regional Agricultural Research Station, Nandyal, ANGRAU, Andhra Pradesh for providing the facilities for smooth conduct of the experiment.

\section{REFERENCES}

Arya RL, Krishnamurthy V, Amarnath S, Roy S, Chandrasekhara Rao C \& Chanda S (2011) Effect of spacing and topping levels on yield and quality of jati tobacco (Nicotiana tabacum L.) grown in north bengal. Tobacco Research 37(1): 40-41.

Czubacka A, Doroszewska T \& Trojak-Goluch A (2012) Agronomic characteristics of transgenic tobacco doubled haploids resistant to Potato virus Y. Journal of Food, Agriculture and Environment 10(4): 374-378.

Gomez KA \& Gomez AA (1984) Statistical Procedures for Agricultural Research, $2^{\text {nd }}$ edition. John Wiley \& Sons, New York, pp. 207-215.

Gooden DT, Brown AB, Ellington G, Fortnum BA, Marshall MW \& Reay-Jones F (2011) South Carolina tobacco growers' guide. $90 \mathrm{p}$.

Guo H, Kan Y \& Liu W (2011) Differential expression of miRNAs in response to topping in flue-cured tobacco (Nicotiana tabacum L.) roots. Plos One 6(12): 1-15.

Gupta RK (2002) National resources conservation technologies for black clay soil region of Peninsular India. Journal of Indian Society of Soil Science 50(4): 438-447.

King MJ (1986) Leaf number at topping on yield, grade index and leaf chemistry of a mammoth type tobacco (Nicotiana tabacum L.). Agronomy Journal 78(5): 913-915.

Krishna SK, Krishna Reddy SV \& Krishnamurthy V (2004) Effect of spacing, levels of nitrogen and topping on yield and quality of irrigated natu tobacco (Nicotiana tabacum L.) grown in alfisols of Andhra Pradesh. Indian Journal of Agronomy 49 (2): 124-127.

Kumaresan M \& Palanichamy K (2002) Performance of chewing tobacco genotypes with varying levels of spacing, nitrogen and topping. Tobacco Research 28: 76-78.

Kumaresan M, Harishu Kumar P, Chandrasekara Rao C, Swamy AVSR \& Athinarayanan R (2008) Preliminary investigations on the performance of bidi tobacco hybrid (Nicotiana tabacum L.) GJH-108 for chewability in Tamil Nadu. Tobacco Research 34(1-2): 93-95.

Kumaresan M, Manoharan K \& Palanichamy K (2001) Effect of nitrogen and topping levels on the yield of chewing tobacco at Vedaranyam. Tobacco Research 27: 73-74.

Patel JR, Ghelani LM, Patel ML, Kocha RP \& Mistry GJ (2003) Effect of spacing and nitrogen levels on cured leaf yield and quality of bidi tobacco hybrid GTH-1 (Nicotiana tabacum L.) under middle Gujarat condition. Tobacco Research 29: 27-30.

Reddy SVK, Kasturi Krishna S \& Prasad Rao JAV(2003) Effect of nitrogen, level and time of topping on productivity and quality of FCV tobacco variety K-326 grown in irrigated Alfisols of Andhra Pradesh. Tobacco Research 29: 148-154.

Reddy VS, Kumaraswamy AS, Setty MVN, Janardhan KV \& Nanje Gowda D (1997) Response of FCV tobacco varieties to dates of planting and levels of topping. Tobacco Research 23: 46-50.

Reed TD, Johnson CS, Semtner PJ \& Wilkinson CA (2012) Flue-cured tobacco production guide in cooperation with the virginia bright Flue-Cured. Tobacco Board, $140 \mathrm{p}$.

Sannibabu M, Deo Singh K \& Athinarayanan R (2014) Tip leaf management practices for maximizing ripe leaf production of NLS Grown FCV Tobacco. Tobacco Research 40(1): 28-34.

Singh KD, Tripathi SN \& Pandey AK (2000) Influence of topping on yield, physical leaf quality parameters and economic return in chewing tobacco. Tobacco Research 25(1): 18-22. 